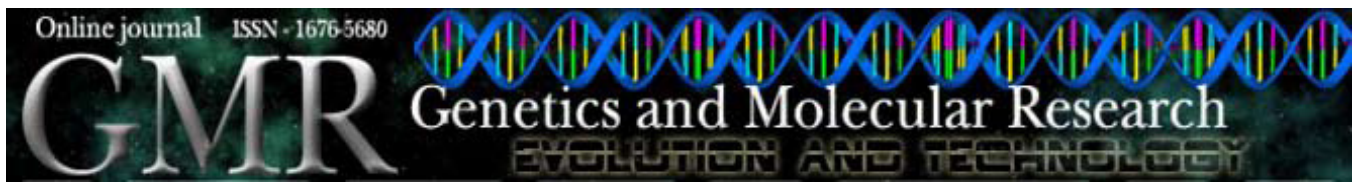

Short Communication

\title{
The impact of forest exploitation on Amazonian stingless bees (Apidae, Meliponini)
}

\author{
G.C. Venturieri \\ Corresponding author: G.C. Venturieri \\ E-mail: giorgio@cpatu.embrapa.br
}

Laboratório de Botânica, Embrapa Amazônia Oriental, Belém, PA, Brasil

Genet. Mol. Res. 8 (2): 684-689 (2009)

Received December 12, 2008

Accepted January 26, 2009

Published June 9, 2009

\begin{abstract}
The protocols available to sustainably exploit natural forest resources are known as "sustainable forest management". This type of management generally does not take into account the effect of timber exploitation on pollinators. Stingless bees, which include many species that play an important role as pollinators and are quite diverse in the Amazon, preferentially make their perennial nests in the base of hollow trees. Normally, during sustainable exploitation of trees, hollow trees are not cut down; however, predatory exploitation of such trees could severely affect natural populations of this pollinator group.
\end{abstract}

Key words: Trees; Bees; Cavities; Nesting; Timber industry 
Since the tropical forests of Asia have been exhausted, the Amazon has become the focus of attention for the scientific community, conservationists and for the industries that commercialize tropical wood worldwide. To increase the exportation of wood without causing irreversible damage to the remaining forests is a considerable challenge. After Russia, Brazil has the largest area of forests (more than double the area Canada has, the third in ranking), with more biomass in these forests than any other country (FAO, 2001). There are strong reasons for the Brazilian wood industry to participate in international markets, especially when such a demand would increase efficiency and reduce negative social and environmental impacts. The social, economical and environmental chaos in the forest sector in Southeast Asia (Macqueen, 2004) is a good example of what happens when a rise in production is ill planned.

Currently, protocols are available to exploit natural forest resources in a sustainable way, known as "sustainable forest management". In principle, this involves modern forestry techniques, combined with the monitoring of economically important species, using parameters such as tree distribution and diameter. However, this type of management generally does not take into account other biological aspects of forests (e.g., its effect on natural pollinators). The cutting of lianas, which serves to improve the growth of the selected species and to reduce damage to nearby trees in case the selected tree is cut down, is one such type of handling (Vidal et al., 1997). Clearly, this type of management has an important impact on pollinators because many lianas are excellent nectar suppliers, flowering in the forest canopy. Many bees, especially the larger species, nourish on liana flowers. These bees that fly over the canopy and travel long distances are important for cross pollination and plant gene flow, fundamental elements for maintaining genetic diversity.

Studies by Bawa $(1974,1990)$, in tropical rain forests of Central America, show that about $98 \%$ of all plants depend on pollination driven by animals. Different from forests in temperate regions, wind pollination is relatively uncommon. Vertebrates, such as birds, bats and other non-flying mammals can be pollen vectors (Faegri and van der Pijl, 1979; Pesson and Louveaux, 1984; Proctor et al., 1996); but most animal-pollinated plants make use of invertebrates (Kress and Beach, 1994). Within the group of invertebrates, bees play a major role (Janzen, 1967; Frankie, 1975; Bawa et al., 1985; Frankie et al., 1976, 1983, 1990; Bawa, 1990; Endress, 1994; Momose et al., 1998). The role of the Apoidea in pollination is even more noticeable when we consider the trees that constitute the canopy and the middle stratum. These trees not only comprise almost all species exploited by the timber industry, but they are also auto-incompatible, which means they need vectors to transfer pollen from one tree to another, sometimes over great distances (Bawa et al., 1985; Bawa, 1990; Renner and Feil, 1993; Kress and Beach, 1994).

Stingless bees are highly eusocial insects that live in colonies varying from hundreds up to several thousands of individuals (Sakagami, 1982). After insemination and the start of egg-laying, the queen's abdomen becomes enlarged (physogastric), which implies that she will not be able to fly anymore and will stay in the same colony as long as she lives. Consequently, colonies are perennial, and occupy the same hollow through various generations. Obviously, the continuous removal of trees with a diameter larger than $50 \mathrm{~cm}$ will, over the medium to long run, negatively affect the density of stingless bee's nests. The consequent lower density of bees will affect the reproductive biology of many tree species; the decline of pollinator populations will result in a reduced seed set.

Stingless bees are a diversified group, with their greatest diversity and abundance in the Amazon region (Michener, 2000). They are among the most frequent visitors of flowers of tropical trees in Asia, both in the canopy and in the understory (Momose et al., 1998); their importance for 
pollination in agricultural and natural pollination has already been demonstrated for several species (Heard, 1999; Maués, 2001; Venturieri, 2000, 2003; Slaa et al., 2006).

This group uses several types of substrates for nesting (Roubik, 2006), but most species use existing cavities in living trees to build their nests (Eltz et al., 2003). The genus Melipona is the most numerous among the stingless bees (Silveira et al., 2002); it occurs exclusively in the Neotropics, with the majority of its species occurring in the Amazon. Melipona includes the biggest and the heaviest individuals; therefore, they are the most adapted to flying long distances in their search for food (up to 2000 m; see Roubik and Aluja, 1983; van Nieuwstadt and Iraheta, 1996; Araujo et al., 2004). Except for Melipona quinquefasciata, which nests in ground cavities, all species of this genus use tree hollows to make their nests (Figure 1A). Most such nests are found near the base of trees, where hollows can reach large volumes. In regions of the Amazon, where the original forest has been cleared, some Melipona species that need large hollows and therefore big trees have become very rare. This has happened to M. fuliginosa (the largest bee of the genus, Figure 1B), M. melanoventer (Figure 1D) and two subspecies of $M$. seminigra. Other species, such as $M$. rufiventris flavolineata (Figure 1C), are adapted to trees with smaller diameters and are also nest at the base of trees that stand in flood areas. Melipona compressipes fasciculata, which nests in trees of coastal regions in the northeast part of the Amazon, such as "siriuba" (Avicennia germinans Avicenniaceae), seems to have the ability withstand human occupation.

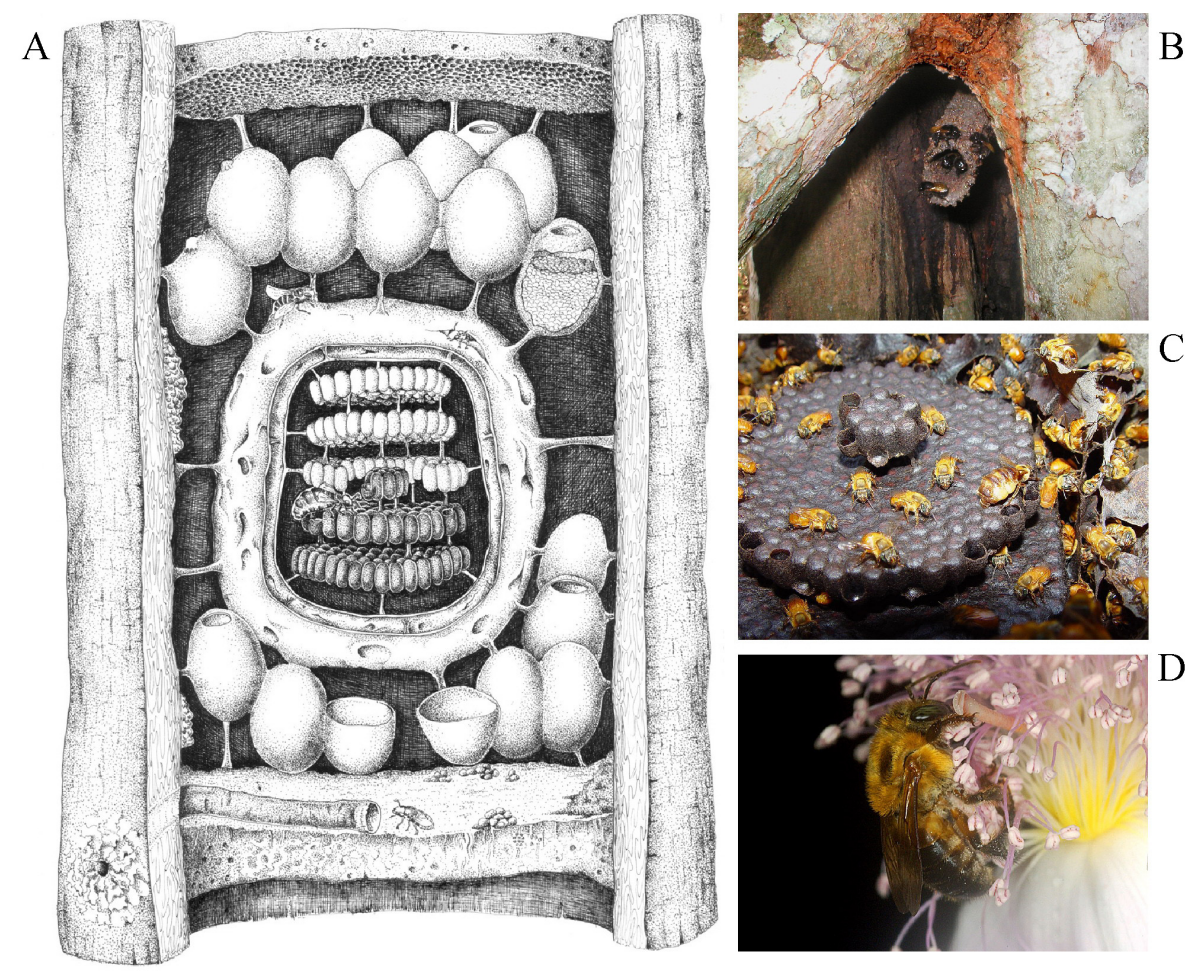

Figure 1. Amazonian stingless bees. A. Schematic drawing of a natural nest of Melipona bees; B. Nest entrance of M. fuliginosa; C. Internal view of a nest of M. flavolineata; D. M. melanoventer pollinating Bixa orellana, an important South American crop (Original drawings by S. Cordeiro, photos by G.C. Venturieri). 
Eltz et al. (2003) and Samejima et al. (2004), while studying the forests of Borneo, in Malaysia, observed that most bee nests occurred in trees of the forest at the climax stage, having diameter at chest-height larger than $50 \mathrm{~cm}$. These trees are exactly the kind that the timber industry look for and exploit. Eltz et al. (2003) and Samejima et al. (2004) also determined that bee species prefer certain trees over others for nesting (see also Antonini and Martins, 2003; Martins et al., 2004). Although these sort of comprehensive studies in general are limited, the Amazon forest has characteristics of relations between bee nesting and tree species similar to those of some Asian tropical forests.

In the model of sustainable forest management implemented in Brazil, and adopted and regulated by the Brazilian Ministry of Environment (IBAMA), as well by other independent NGOs acting in Brazil, it is recommended to not extract trees with hollows during forest exploitation. In the proposed model, these trees would better serve as seed banks, because of their already lowered commercial value when exploited for their wood. However, most timber exploitation does not adopt such recommendations (Figure 2). An additional problem is that most wood originating from the natural Amazon forests is used for the internal market and is informally commercialized (Table 1; Smeraldi and Veríssimo, 1999), avoiding environmental regulations and not respecting the rules of "good management".

Table 1. Consumption of wood in 1997 originating from the Brazilian Amazon.

\begin{tabular}{lcccc}
\hline Destination & International market & Brazilian Amazon & São Paulo State & other Brazilian states \\
\hline Million of $\mathrm{m}^{3}$ & 4.0 & 2.7 & 5.6 & 14.0 \\
$\%$ of total & $14 \%$ & $10 \%$ & $20 \%$ & $56 \%$ \\
\hline
\end{tabular}

Source: Smeraldi and Veríssimo (1999).

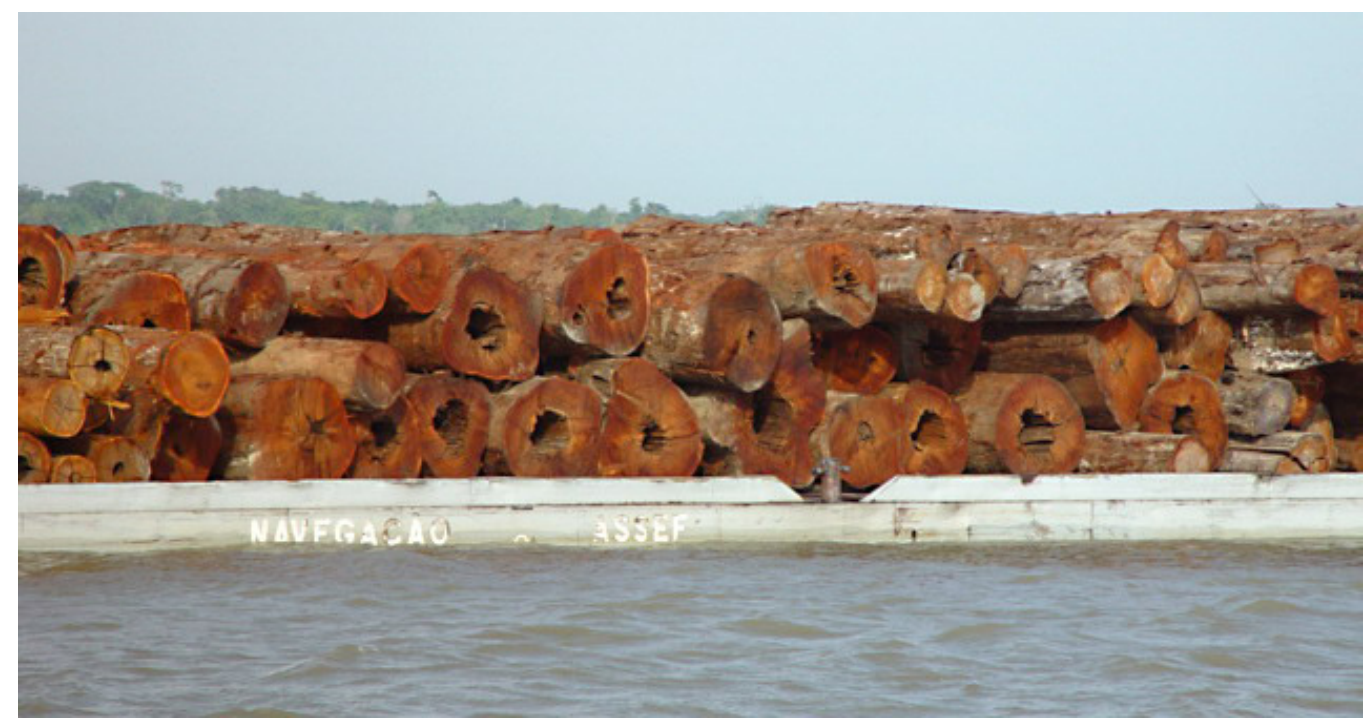

Figure 2. Transport of trunks on a river in the Amazon; note the high frequency of trunks with hollows. It can be seen that the hollow trunks are among those with the largest diameters. 
The continuous commercialization of wood, even when the current rules of forest management are respected, will in the long run jeopardize the survival of forests because of the strong reduction in nesting places of key pollinators, including stingless bees. In particular, the exploitation of trees with diameters over $50 \mathrm{~cm}$ will dramatically diminish the nesting possibilities of many species of this group (Eltz et al., 2003; Samejima et al., 2004).

We recommend the following actions to control the exploitation of timber based on stingless bee's nesting necessities: A) perform more studies on their nesting biology, determine what trees they use, census the populations of Amazonian stingless bees, and develope standardized procedures for evaluating their occurrence in the Amazon forest; B) introduce artificial nesting boxes for stingless bees in managed forests, in order to minimize the effects of human exploitation of trees, which reduces nesting cavity availability; C) monitor and control the cutting of trees containing natural nesting cavities; D) support management strategies that determine the trees that offer potential nesting sites; E) provide better information to timber exploiters and technicians about the effects of the cutting trees that hold stingless bee nests on the reproduction of commercially important tree species, and F) offer better information to wood explorers and technicians about the importance of maintaining plant species that serve as food for natural populations of stingless bees and pollinators in general.

\section{ACKNOWLEDGMENTS}

I dedicate this article to Professor Warwick E. Kerr in homage of his inestimable contributions to the study of bees. I also thank Felipe Contrera, Vera Lucia Imperatriz-Fonseca, Carmen García Fernándes, and Anonymous reviewers for valuable comments on the article and the Botany Laboratory of Embrapa Amazônia Oriental for the use of its facilities and administrative help. This study was funded by FAO.

\section{REFERENCES}

Antonini Y and Martins RP (2003). The value of a tree species (Caryocar brasiliense) for a stingless bee Melipona quadrifasciata quadrifasciata. J. Insect Conserv. 7: 167-174.

Araújo ED, Costa M, Chaud-Netto J and Fowler HG (2004). Body size and flight distance in stingless bees (Hymenoptera: Meliponini): inference of flight range and possible ecological implications. Braz. J. Biol. 64: 563-568.

Bawa KS (1974). Breeding systems of tree species of a lowland tropical community: evolutionary and ecological considerations. Evolution 28: 85-92.

Bawa KS (1990). Plant-pollinator interactions in tropical rain forests. Annu. Rev. Ecol. Syst. 21: 399-422.

Bawa KS, Bullock SH, Perry DR, Coville RE, et al. (1985). Reproductive biology of tropical lowland rain forest trees. II. Pollination systems. Am. J. Bot. 72: 346-356.

Eltz T, Brühl CA, Imiyabir Z and Linsenmair KE (2003). Nesting and nest trees of stingless bees (Apidae: Meliponini) in lowland dipterocarp forests in Sabah, Malaysia, with implications for forest management. For. Ecol. Manage. 172: 301-313.

Endress PK (1994). Diversity and Evolutionary Biology of Tropical Flowers. Cambridge University Press, Cambridge.

Faegri K and van der Pijl L (1979). The Principles of Pollination Ecology. 3rd edn. Pergamom, Oxford.

FAO (Food and Agriculture Organization) (2001). State of the World's Forests. FAO, Rome.

Frankie GW (1975). Tropical Forest Phenology and Pollinator Plant Coevolution. In: Coevolution of Animal and Plants (Gilbert LE and Raven PH, eds.). University of Texas Press, Austin, 192-209.

Frankie GW, Opler PA and Bawa KS (1976). Foraging behaviour of solitary bees: implications for outcrossing of a Neotropical forest tree species. J. Ecol. 64: 1049-1057.

Frankie GW, Haber WH, Opler PA and Bawa KS (1983). Characteristics and Organization of the Large Bee Pollination System in the Costa Rican Dry Forest. In: Handbook of Experimental Pollination Biology (Jones CE and Little RJ, eds.). Scientific and Academic Editions, New York, 411-447. 
Frankie GW, Vinson SB, Newstrom LE, Barthell JF, et al. (1990). Plant Phenology, Pollination Ecology, Pollination Behaviour and Conservation of Pollinators in Neotropical Dry Forest. In: Reproductive Ecology of Tropical Forest Plants (Bawa KS and Hadley M, eds.). UNESCO and Parthenon Publishing Group, Carnsforth and Paris, 37-47.

Heard TA (1999). The role of stingless bees in crop pollination. Annu. Rev. Entomol. 44: 183-206.

Janzen DH (1967). Synchronization of sexual reproduction of trees within the dry season in Central America. Evolution 21: 620-637.

Kress WJ and Beach JH (1994). Flowering Plant Reproductive Systems. In: La Selva: Ecology and Natural History of a Neotropical Rain Forest (McDade LA, Bawa KS, Hespenheide HA and Hartshorn GS, eds.). Chicago University Press, Chicago, 142-182.

Macqueen D (2004). Exportando Sem Crises: A Indústria de Madeira Tropical Brasileira e os Mercados Internacionais. International Institute for Environment and Development, London.

Martins CF, Cortopassi-Laurino M, Koedam D and Imperatriz-Fonseca VL (2004). Espécies arbóreas utilizadas para nidificação por abelhas sem ferrão na caatinga (Seridó, PB; João Câmara, RN). Biota Neotrop. 4: 1-8.

Maués MM (2001). Síndromes de Polinização e Biologia Floral de Espécies Madeireiras da Amazônia e Implicações para o Manejo Florestal. In: Silvicultura na Amazônia Oriental (Silva NM, Carvalho JOP and Yared JAG, eds.). Embrapa Amazônia Oriental/DFID, Belém, 85-116.

Michener CD (2000). The Bees of the World. Johns Hopkins University Press, Baltimore and London.

Momose K, Yumoto T, Nagamitsu T, Kato M, et al. (1998). Pollination biology in a lowland dipterocarp forest in Sarawak, Malaysia. I. Characteristics of the plant-pollinator community in a lowland dipterocarp forest. Am. J. Bot. 85: 1477-1501.

Pesson P and Louveaux J (1984). Pollinisation et Productions Végétales. INRA, Paris.

Proctor M, Yeo P and Lack A (1996). The Natural History of Pollination. Timber Press, Portland.

Renner SS and Feil JP (1993). Pollinators of tropical dioecious angiosperms. Am. J. Bot. 80: 1100-1107.

Roubik DW (2006). Stingless bee nesting biology. Apidologie 37: 124-143.

Roubik DW and Aluja M (1983). Flight ranges of Melipona and Trigona in tropical forest. J. Kans. Entomol. Soc. 56: 217-222.

Sakagami SF (1982). Stingless Bees. In: Social Insects. Vol. III (Hermann HR, ed.). Academic Press, New York, 361-423.

Samejima H, Marzuki M, Nagamitsu T and Nakasizuka T (2004). The effects of human disturbance on a stingless bee community in a tropical rainforest. Biol. Conserv. 120: 577-587.

Silveira FA, Melo GAR and Almeida EAB (2002). Abelhas Brasileiras: Sistemática e Identificação. Ministério do Meio Ambiente, Fundação Araucária, Belo Horizonte.

Slaa EJ, Chaves LAS, Malagodi-Braga KS and Hofstede FE (2006). Stingless bees in applied pollination: practice and perspectives. Apidologie 37: 293-315.

Smeraldi R and Veríssimo A (1999). Hitting the Target: Timber Consumption in the Brasilian Domestic Market and Promotion of Forest Certification. IMAZON, Belém.

van Nieuwstadt MGL and Iraheta CER (1996). Relation between size and foraging range in stingless bees (Apidae, Meliponinae). Apidologie 27: 219-228.

Venturieri GC (2000). A Ecologia Reprodutiva do Taxi-branco (Sclerolobium paniculatum var. paniculatum Vogel) e do Paricá (Schizolobium amazonicum Huber ex Ducke) leg: Caesalpinioideae e a Influência da Melitofilia na Polinização dessas Árvores Amazônicas. Doctoral thesis, Instituto de Biociências, USP, São Paulo.

Venturieri GC (2003). Plantas Visitadas por Meliponina no Estado do Pará. Anais do $54^{\circ}$ Congresso Nacional de Botânica, Belém, 261-263.

Vidal E, Johns J, Gerwig JJ, Barreto P, et al. (1997). Vine management for reduced-impact logging in eastern Amazonia. For. Ecol. Manage. 98: 105-114. 